\title{
Extraction of DNA from small sections of frozen tissue with simultaneous histological examination
}

\author{
F E COTTER,* P A HALL, $†$ B D YOUNG* The Imperial Cancer Research Fund, Departments of \\ ${ }^{*}$ Medical Oncology, and $\dagger$ Histopathology, St Bartholomew's Hospital, London
}

SUMMARY Though analysis of small sections of biopsy material by molecular techniques permits increased sensitivity, it also requires accurate histological examination of the tissue in order to reduce sampling error. A technique for the extraction of DNA from small sections of frozen biopsy material with simultaneous histological examination from adjacent sections is described that may enhance the accuracy of characterisation of the tissue, particularly where there is focal variation. The quality of the DNA obtained enables a full range of molecular studies to be carried out.

Recent advances in molecular pathology have lead to greater competition for material from limited quantities of tumour tissue. The use of small amounts of biopsy material, however, may lead to an increase in sampling errors, particularly where the disease is focal. ${ }^{1}$ A technique has been devised for the extraction of DNA from a minimal quantity of freshly frozen tissue that permits accurate histological examination at the same time. This method has the advantage of preserving the remainder of the tissue for further investigations, while providing enough DNA for Southern blot analysis or cosmid cloning.

\section{Material and methods}

Snap frozen biopsy specimens stored in liquid nitrogen were used. The range of block size was from $0.25 \times 0.5$ $\times 0.5 \mathrm{~cm}$ to $1 \times 0.5 \times 0.5 \mathrm{~cm}$. Twenty 10 micron cryostat sections were cut and collected on a clean glass slide placed on the roll bar support, adjacent to the blade. Five micron cryostat sections were then taken for histopathological and immunohistochemical examination. The cut sections were placed immediately into a $50 \mathrm{ml}$ Falcon tube containing lysis mixture (solution of $0.32 \mathrm{M}$ sucrose; $10 \mathrm{~mm}$ Tris at $\mathrm{pH}$ $7.5 ; 5 \mathrm{~mm}$ magnesium chloride; $1 \%$ Triton $\mathrm{X}-100$ ) at $4^{\circ} \mathrm{C}$. The tube was shaken thoroughly and then spun at $2400 \mathrm{rpm}$ for 20 minutes. The supernatant was discarded and the remaining nuclear pellet resuspended in $2.5 \mathrm{ml}$ of sodium chloride and edetic acid solution ( $0.075 \mathrm{M}$ sodium chloride and $0.024 \mathrm{M}$ edetic acid). One hundred and twenty five $\mu \mathrm{l}$ of $10 \%$ sodium dodecyl sulphate and $50 \mu \mathrm{l}$ of proteinase $\mathrm{K}(10 \mathrm{mg} / \mathrm{ml})$ were added and incubated overnight at $37^{\circ} \mathrm{C}$, or for

Accepted for publication 5 May 1988 three hours at $55^{\circ} \mathrm{C}$. Phenol and chloroform in equal volumes were added to the DNA. The mixture was then centrifugated at $9000 \mathrm{rpm}$ for 10 minutes at room temperature and the aqueous solution (above the phenol) extracted. This was repeated until the interface was clear. Another chloroform extraction was done in the same way and the aqueous solution was placed in a clear tube (about $2 \mathrm{ml}$ ), and $0.25 \mathrm{ml}$ of $3 \mathrm{M}$ sodium acetate and $5.5 \mathrm{ml}$ of precooled absolute alcohol $\left(\right.$ at $\left.-20^{\circ} \mathrm{C}\right)$ were added. The precipitate of DNA was spooled out. Fuller precipitation of DNA may occur if the mixture is kept at $-20^{\circ} \mathrm{C}$ overnight. The spooled DNA was dipped into absolute alcohol to remove excess salt and allowed to dry in air for 10 minutes. The DNA was resuspended in $110 \mu \mathrm{l}$ of TE buffer (0.01 M Tris at pH 7.5 and $0.001 \mathrm{M}$ edetic acid) and stored at $4^{\circ} \mathrm{C}$. Ten $\mu$ l of DNA solution was removed so that the concentration and purity could be calculated by optical density.

\section{Results}

The technique was used on 73 frozen samples from various tissues. In all cases 20 or more sections provided enough DNA of adequate purity for Southern blotting examination (fig 1) or cosmid library construction (fig 2). The mean quantity of DNA extracted from each sample was $109 \mu \mathrm{g}$ (range 50 to 140). The quality of histology and immunohistochemistry on adjacent sections was good.

\section{Discussion}

Studies requiring freshly frozen tissue are becoming increasingly common so that more diagnostic information can be provided than is available from conventional morphological examination of paraffin wax 


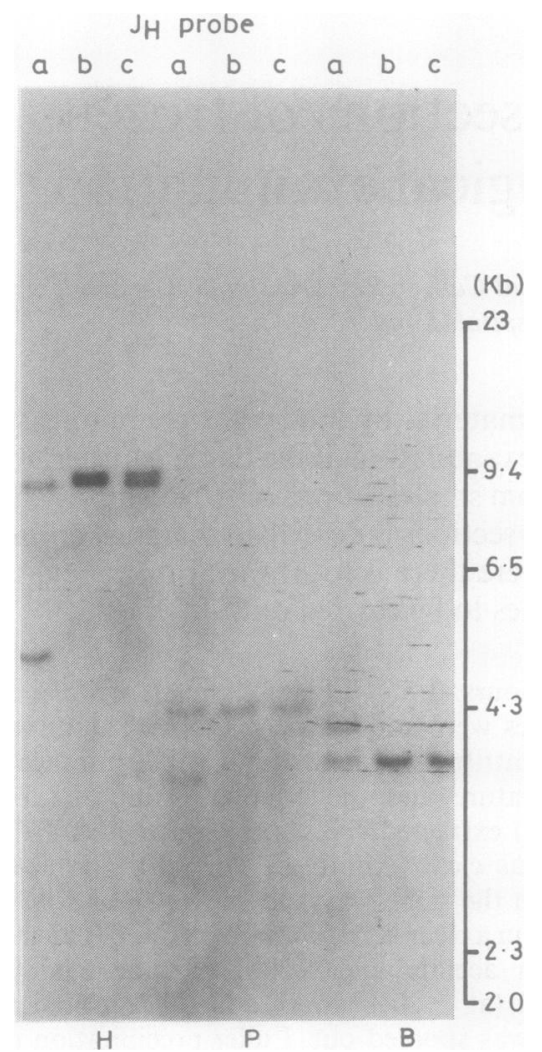

Fig 1 Southern blot using three samples of DNA extracted by the technique described. Hybridisation was carried out with the immunoglobulin heavy chain probe $\left(J_{H}\right)$ after three restriction enzyme digests. $(H=H$ ind $I I I, P=P$ st $I$, $B=B g l I I$ ).

embedded specimens. These include immunohistochemical staining and molecular and cytogenetic studies. Amounts of tissue are often small. We have described a technique for the purification of DNA from minute quantities of frozen tissue than can be extracted while the remainder of the sample remains frozen. Histological examination of adjacent tissue sections was carried out, permitting close correlation among molecular, cytogenetic, morphological, and immunostaining studies. Recent reports ${ }^{123}$ have suggested that there is focal histological variation even within small pieces of tumour tissue in some neoplastic diseases. This could lead to considerable sample variation and error if studies are carried out on minute quantities of tissue. The method we have described may help to keep this potential error to a minimum as well as facilitating the study of small areas of variation individually, even within single small blocks of tissue.

This is an effective and simple method of extracting DNA to permit molecular studies of small quantities of frozen tissue while the remainder of the blocks

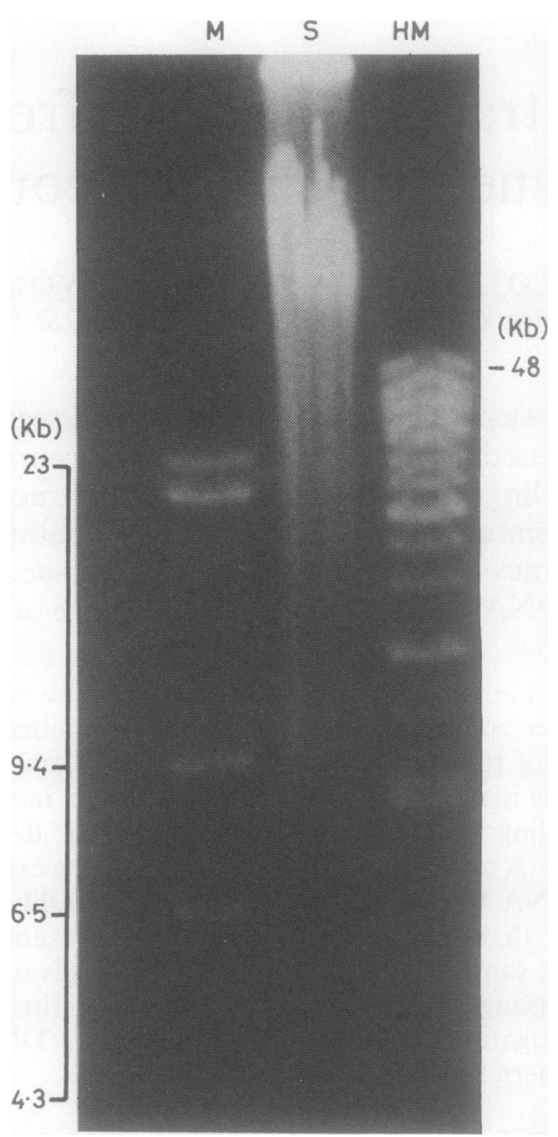

Fig 2 Sample (S) of undigested DNA extracted by the technique described showing the high molecular weight and purity, adequate for the formation of a cosmid library. Electrophoresis was performed on a $0.7 \%$ agarose gel and stained with ethidium bromide. Molecular mass markers are on the right (HM) and left $(M)$ and are indicated in $K b$.

remain frozen. Additional histopathological findings may readily be made from adjacent sections to permit more accurate correlation and characterisation of neoplastic disease, particularly where focal variation is present.

\section{References}

1 Islam A. New instrument for longitudinal hemisectioning of undecalcified marrow cores, for simultaneous processing and examination with useful and complementary techniques. J Clin Pathol 1987;40:112-6.

2 Hu E, Weiss LM, Warnke R, Sklar J. Non-Hodgkin's lymphoma containing both B and T cell clones. Blood 1987;70:287-92.

3 Bos JL, Fearon ER, Hamilton SR, et al. Prevalence of ras gene mutations in human colorectal cancers. Nature 1987;327:293-7.

Requests for reprints to: Dr F E Cotter, ICRF Department of Medical Oncology, St Bartholomew's Hospital, West Smithfield, London ECIA 7BE, England. 